образомъ, въ силу того, что сама увеличенная матка препятствуетъ быстрому истечевію крови и вмьсть съ тьыъ развитію полной картины бользни. Быть можетъ сама беременность, обусловливая рядъ явлевій застоя и переполненія сосудовъ брюшной полости, служитъ моментомъ, предрасполагающимъ къ разрыву посл'вднихъ въ перитонитическихъ сращеніяхъ, в’ виду чего $H$. съ положительностью высказывается противъ искусственшаго вызыванія сращеній, вообще, у женщинъ, погущихъ заберемевить впосльдствів, и противъ вентрофиксаціи при тьхъ же условіяхъ, въ частности При ранней постановкъ діагноза въ огисанномъ случаъ едивственнымъ средствомъ могло бы быть только чревосьченіе съ остановкою кровотеченія путемъ либо прямой перевязки кровоточащихъ сосудовъ, либо въ крайнемъ случа', томпонады брюшной полости іодоформенвой марлей.

\title{
К. Вальтеръ.
}

121. H. Fritsch. Ueber Auskratzung des Uterus bei Puerperalfieber. (Deutsche Medicinische Wochenschrift, 추 16, 1891 г.). Выскабливаніе матки при родильной горячкћ.

Бактеріологическій взглядъ на этіологію посльродовыхъ лихорадокъ приводитъ къ двумъ средствамъ бороться съ ними: в0-первыхъ педопускать микрооргавизмы въ родовые пути-профилактика и 2) уничтожать попавшихъ уже-антисептика. Если бы можно было точно знать моментъ ихъ ввњдренія въ организмъ, то посльродовыя забольванія изльчивались бы простымъ прощывавіемъ. Но на практикъ это невозможно и достаточно ньсколькихъ часов'ъ, чтобы болжзнь приняла угрожающій характеръ. Въ подобвыхъ слуqаяхъ простое промываніе уже не можетъ помочь, и необходимо примьнить болье дњйствительное средство, а именно, по аналогіи съ хирургіей вообщевыскабливавіе. По $E$. von Braun'у посл'ьродовыя лихорадки раздъляются на піэмическія, септическія и сапрофическія. Въ посльдвихъ, гдъ причиной лихорадки являются сапрофиты и образованные ими птомаивы-удалевіе ихъ должно привести пользу. Французскіе авторы смотрятъ на выскабливаніе, какъ на болье радикальное очищеніе, чъмъ промываніе. Авторъ производилъ выскабливаніе посльродовыхъ матокъ уже въ теqеніе 20 льтъ. Самая операція выскабливанія совершенно безопасна, а возможность перфорировать матку, всльдствіе ея дряблости зависитъ только отъ чисто ивдивудуальныхъ, случайныхъ причинъ. Несмотря ва безопасность и легкость выполневія операціи, авторъ не совътуетъ ея примънять, исходя изъ сльддующихъ положевій. По начальной картинь эндометрита, невозможно сказать, съ какой ивфекдіей приходится им'ьь дь'ло: съ сапрофитами или стрептококками, и только дальныйшее теченіе даетъ точный отвътъ. Исходной точкой инфекціи, авторъ считаетъ шейку, наиболье подвергающуюся пораненіямъ и растяженію, и микрококки, попавшіе въ вее, при ея посль'дующемъ сокращевіи, механически попадаютъ въ глубокія слои ткани и отсюда распространяются въ параметрій и въ полости тейки, какъ можно видысть въ протоколахъ вскрытій. Посредствомъ выскабливанія не удаляется очагъ заразы, лежащій въ 
глубинъ тканей, а только уничтожаетъ ивпапсулированіе стрептококковъ и ухудшаетъ дъло, такъ какъ липаетъ органъ покоя-лучшаго противувоспалительнаго средства. 100 случаевъ Braun'а, гдъ посль' выскабливавія лихорадка прекращалась, Fritsch объясняетъ тъь'ь, что здъсь были легкіе случаи, которые выздоров'ьли бы и безъ выскабливанія, и главную роль приписываетъ прижиганіг іодной настойкой, результатомъ чего было сильная инволющія матки. Въ одномъ случа屯 было бы раціональво выскабливаніе, когда посль' промыванія, температура падаеть и потомъ снова повыпается, объясняя это повышеніе новым возрожденіемъ микрококковъ и образованіемъ птомаинов'ъ, но изъ опыта авторъ убъдился, что и въ подобныхъ случаяхъ выскабливаніе не помогаетъ, временное понижевіе температуры объясняется дъйствіемъ антисептическаго вещества и удалевіещъ накопившихся отдьвеній; а сль́дующее повышеніе продолжающимся процессомъ въ глубинъ тканей. 0тносительно остатковъ дытскаго мъста, авторъ совьтуетъ ихъ удалять, но не изъ боязни эндометрита или сапреміи, а всльцдствіе кровотеченій и вепріятныхъ посльдствій задержанной ивволюпіи матки.

п. Садовскій.

122. K. Olshausen. Beitrag zu puerperalen Psychosen, speciell den nach Eclampsie auftretenden. (Zeitschr. f. Geb. u.Gyn., Bd. XXI, H. 2, 1891). Къ вопросу о посльродовыхъ психозахъ и въ частности о психозахъ посль энлампсіи.

Нельзя отрицать, что ослабляющіе организщъ моменты во .время какъ самаго акта родовъ, такъ и посльродового періода, могуть, въ связи съ чисто психическими условіями, тьмъ болье при существованіи насльдственнаго предрасположевія, повлечь за собоп дупевное забольвавіе въ послжродовомъ періодъ. Но рядомъ съ подобными случаями несомньнно существуютъ и другіе, указывающіе на самую тьскную связь психоза съ тяжелымъ ивфекціоннынъ забольваніещъ родильницъ, связь, мало еще выясненную какъ съь клинической, такъ и съ анатомической точекъ зрбвія. По наблюдевіямъ $O$. острые психозы наичаще являются спутниками посльродовой піэміи и язвеннаго эндокардита, р'же съ ними приходится ищьть дъло при септицеміи. ПІіэія при этомъ можетъ протекать скрытно и не быть опредълева при жизни родильницы, выражаясь острым пораженіемъ щозговыхъ оболочекъ и вещества мозга, въ особенности въ видъ капиллярныхъ эмболій, легко проскальзывающихъ незам'ченным и на анатомическомъ столь. Пораженія брюшины, суставовъ и прочихъ органовъ щожеть при этомъ и не наблюдаться. Самъ $O$. имъль сльдующій случай: 19-ти льттяя I рага родила легко и нормально кром' незначительнаго разрыва промежности. Къ вечеру второго дня $\mathrm{t}^{\circ} 38,1^{\circ}$.при отсутствіи какихъ-бы то ни было мыстныхъ явлевій. На 3-й день сильная головная боль $\mathrm{t}^{0} 39,1^{\circ}$ На петвертый $\mathrm{t}^{\circ} 38^{\circ}$ y. $-39,8^{\circ}$ в. при тьххъ же явленіяхъ и рузкомъ психическошь возбужденіи. На 5-й день галлюцинаціи слуха и наконецъ на 12-й день посл'ь родовъ при постоянно продолжагощейся съ небольшими ремиссіями лихорадкъ и при полномь огсутствіи болей въ животь্ посл'ъдовала смерть. На вскрытіи найденъ свъжій теморрагическій пахименин- 